\title{
Wtadystawa Szulakiewicz
}

Uniwersytet Mikołaja Kopernika w Toruniu

\section{Czasopisma historyczno-oświatowe źródłem informacji o polskiej historii wychowania}

\section{Uwagi wstępne}

Celem autorki artykułu jest przedstawienie ogólnego spojrzenia na czasopisma historyczno-oświatowe biorąc pod uwagę ich wartość jako źródła do dziejów polskiej historii wychowania. W swoich rozważaniach przyjmuję punkt widzenia badacza dziejów polskiej historii wychowania, dlatego analizowane periodyki traktuję jako źródło służące poznaniu rozwoju polskiej historii wychowania w różnych jej aspektach. Bez wątpienia każde $\mathrm{z}$ branych pod uwagę $\mathrm{w}$ tym artykule czasopism wymaga odrębnej analizy i opracowania. W prezentowanym szkicu przedstawiam jedynie sporadyczne odniesienia do każdego $\mathrm{z}$ nich $\mathrm{w}$ celu egzemplifikacji przedstawianych tez ${ }^{1}$. Jak powszechnie wiadomo listę czasopism historycznooświatowych tworzą, ujmując problem chronologicznie: „Minerwa Polska” („Minerwa”) $)^{2}$, Przegląd Historyczno-Oświatowy” (,Przegląd”) ${ }^{3}$, „Rozprawy

${ }^{1}$ Znacznie częściej przywołuję przykłady z „Biuletynu Historii Wychowania” z tego wzglę$\mathrm{du}$, że jak dotychczas brak opracowania na temat tego pisma, poza zestawieniem zawartości patrz: A. Gołębiewska, Biuletyn Historii Wychowania za lata 1994-2004. Przeglad zawartości, „Rozprawy z Dziejów Oświaty" 2006, s. 318-322.

2 J. Hellwig, Minerwa Polska (1927-1929) - jako pismo poświęcone historii wychowania, „Przegląd Historyczno-Oświatowy” 1998, nr 3-4, s. 223-228; W. Szulakiewicz, „Minerwa Polska" - czasopismo naukowe poświęcone historii oświaty i wychowania, [w:] Stużbie historii nauki, kultury i edukacji, red. R. Grzybowski i T. Maliszewski, Gdańsk 2006, s. 92-104.

${ }^{3}$ Z okazji 60-lecia „Przeglądu Historyczno-Oświatowego” nr 198 (z roku 2007) pisma poświęcony został jego działalności wydawniczej i zawiera bibliografię za lata 1947-2007. Ponadto opracowania: T. Gumuła, Czterdzieści pięć lat „Przegladu Historyczno-Oświatowego”, [w:] Historia wychowania $w$ kształceniu nauczycieli. Tradycja i współczesność. Teoria i praktyka, red. T. Gumuła, S. Majewski, Kielce 2005, s. 79-93; K. Mrozowska, Ryszard Wroczyński jako redaktor „Przegladu Historyczno-Oświatowego” 1959-1987. Garść wspomnień, [w:] Pedagogika społeczna. Pytania o XXI wiek. Pamięci Profesora Ryszarda Wroczyńskiego, red. A. Przecławska, W. Theiss, Warszawa 1999; T. Nowacki, Trzydziestolecie „Przegladu Historyczno-Oświatowe- 
z Dziejów Oświaty” („Rozprawy”) ${ }^{4}$ i „Biuletyn Historii Wychowania” („Biuletyn”).

Aby przedstawić wartość czasopism historyczno-oświatowych jako źródła do dziejów polskiej historii wychowania, należy odnieść się m.in. do takich kwestii, jak: 1) funkcje czasopism, 2) program pism i struktura, 3) twórcy i skład redakcji czasopism, 4) przynależności periodyków do określonej instytucji naukowej lub towarzystwa jako organu prasowego oraz 5) polska i powszechna historia oświaty prezentowana na łamach czasopism, czyli zakresy tematyczne.

Jednym z kryteriów analizy czasopism są spełniane przez nie funkcje. Wymienione wcześniej czasopisma spełniają te same funkcje, które zwykło się przypisywać czasopismom w ogólności. W literaturze podkreśla się, iż czasopisma naukowe pełnią specyficzne funkcje, obce innym rodzajom publikacji naukowych ${ }^{5}$. Przykładowo Małgorzata Korczyńska-Derkacz przedstawiając klasyfikację funkcji czasopism naukowych wymieniła następujące: anonsująca, integrująca, inspiracyjno-stymulacyjna, korektorską, bibliograficzną i kronikarską $^{6}$. Z kolei Janusz Żarnowski prezentując pisma naukowe z zakresu historii mówi głównie o roli, jaką odgrywa prasa naukowa ${ }^{7}$. Za najważniejszą uważa integrującą rolę czasopism naukowych, z niej wypływają inne zadania, czy też funkcje. Podobnego zdania, na temat roli czasopiśmiennictwa, są autorzy mówiący w ogóle o prasie, w tym także prasie naukowej, uznając, że najważniejszą funkcją jest funkcja społeczna ${ }^{8}$.

W świetle powyższych rozważań należy zapytać jakie funkcje spełniaja wymienione czasopisma. Już na samym początku trzeba podkreślić, że o ile funkcję informacyjną spełnia każde z pism, o tyle informacyjno-oceniająca, czy też funkcję krytyczną spełniają głównie działy Recenzji, które są ważną częścią

go”, „Przegląd Historyczno-Oświatowy” 1989, nr 2; R. Wroczyński, 25-lecie „Przegladu Historyczno-Oświatowego”, „Przegląd Historyczno-Oświatowy” 1983, nr 1.

${ }^{4}$ W. Szulakiewicz, ,Rozprawy z Dziejów Oświaty” (1958-2002). Studium z historii czasopisma, Toruń 2004, ss. 178; taż, „Rozprawy z Dziejów Oświaty” (1958-2002) - pismo historycznooświatowe, [w:] Historia wychowania w kształceniu nauczycieli. Tradycja i wspótczesność. Teoria i praktyka, red. T. Gumuła i S. Majewski, Kielce 2005, s. 71-78.

${ }^{5}$ Szerzej na ten temat: B. Stanosz, A. Nowaczyk, Recenzje z tomów I-V „Zagadnień Naukoznawstwa”, „Zagadnienia Naukoznawstwa” 1971, t. VII.

${ }^{6}$ M. Korczyńska-Derkacz, Problematyka badań nad czasopiśmiennictwem naukowym, „Roczniki Biblioteczne” 1987, t. XXXI, z. 2, s. 285-286.

${ }^{7}$ J. Żarnowski, Czasopisma naukowe z zakresu historii, „Roczniki Biblioteki Narodowej” 1965, t. I, s. 408.

${ }^{8} \mathrm{~Np}$. Mieczysław Kafel uważa, że punktem wyjścia zdefiniowania terminu „funkcja prasy” powinno być określenie zadań, jakie czasopisma spełniają w społeczeństwie, czyli funkcji społecznej. Dopiero tę ogólną funkcję można, jego zdaniem, rozłożyć na funkcje szczegółowe, takie jak: informacyjna, publicystyczną, wychowawczą, rozrywkową, powiadamiania czy komunikowania. M. Kafel, Prasoznawstwo. Wstęp do problematyki, Warszawa 1966, s. 139 i n. 
każdego z nich ${ }^{9}$. Na uwage zasługują także te działy czasopism, które są przekazem wiedzy o życiu naukowym środowiska polskich historyków wychowania. Do nich należy zaliczyć sprawozdania, kroniki, a także bibliografie. Te działy są dopełnieniem obrazu aktywności określonych środowisk, w naszym przypadku środowiska historyków wychowania.

\section{Program i struktura czasopism historyczno-oświatowych}

Przewidywane funkcje zostały zakreślone przez redaktorów (redakcje) w odezwach zamieszczanych w pierwszych tomach czy numerach czasopism. W tychże artykułach wstępnych wskazano też struktury czasopism oraz preferowaną problematykę. Warto zatem odwołać się do treści artykułów wstępnych zatytułowanych zazwyczaj Od Redakcji.

Najstarsze polskie czasopismo, wychodzące w latach 1927-1929, czyli „Minerwę Polską" uznaje się za pierwsze profesjonalne pismo polskich historyków wychowania. Chociaż powstało we Lwowie, to w planach twórców miało mieć (i miało) charakter ogólnopolskiego czasopisma i stanowiło organ ministerialnej Komisji do Badania Dziejów Wychowania i Szkolnictwa w Polsce, jednak już drugi rocznik „Minerwy”, po rozwiązaniu Komisji (1929), ukazał się w 1930 r. jako organ Komisji Historycznej Naukowego Towarzystwa Pedagogicznego ${ }^{10}$. Konieczność jej powołania argumentowano m.in. rozwojem badań historyczno-oświatowych, ale i tym, że inne narody europejskie posiadają już od dawna tego typu periodyki ${ }^{11}$. Na jej strukturę składały się następujące działy: Rozprawy, Notatki i Materiaty, Recenzje, Kronika i Bibliografia. Jej redaktor Stanisław Łempicki - zdołał zachęcić do współpracy jako autorów badaczy przeszłości oświatowo-wychowawczej $\mathrm{z}$ różnych ośrodków akademickich. $\mathrm{W}$ drugim roczniku pisma $\mathrm{S}$. Łempicki, wyrażając radość z jego kontynuacji po dwuletniej przerwie, napisał:

„Minerwa Polska” ma być organem naukowym otwierającym swe łamy dla badań nad dziejami wychowania szkolnictwa i w ogóle oświaty w Polsce... Obok zagadnień i rzeczy polskich które wysuwają się na plan pierwszy - uwzględniać będziemy również zagadnienia $\mathrm{z}$ dziejów wychowania i szkolnictwa narodów obcych, szczególnie te, które pozostają w związku z dziejami

${ }^{9} \mathrm{~W}$ literaturze recenzjom przypisuje się często przede wszystkim rolę informacyjną i zalicza się je do części informacyjno-sprawozdawczej, patrz: T. Ostrowska, Czasopisma w nauce, cz. I, „Przegląd Humanistyczny 1975, nr 9, s. 73.

${ }^{10}$ Więcej na temat pisma: W. Szulakiewicz, „Minerwa Polska”-czasopismo naukowe poświęcone historii oświaty $i$ wychowania, [w:] Stużbie historii nauki, kultury i edukacji, red. R. Grzybowski i T. Maliszewski, Gdańsk 2006, s. 92-104.

${ }^{11}$ Od Redakcji, „Minerwa Polska” 1927, s. 1. „Minerwa” była kwartalnikiem wydawanym nakładem Wydawnictwa Ossolineum (1927) i Naukowego Towarzystwa Pedagogicznego (1929). 
naszych usiłowań i czynów oświatowych. Poświęcona przede wszystkim badaniu naszej przeszłości wychowawczej i szkolnej, nie będzie jednak stronić od rozważania i omawiania pewnych problemów współczesności, zwłaszcza problemów o znaczeniu ogólniejszym i o wartości nieprzemijającej, prawdziwie historycznej ${ }^{12}$.

Te plany nie zostały zrealizowane, gdyż - jak powszechnie wiadomo w 1930 r. ukazał się ostatni rocznik „Minerwy Polskiej” za rok 1929.

Po zakończeniu II wojny światowej powrócono do sprawy powołania pism historyczno-oświatowych ${ }^{13}$. W dwa lata po zakończeniu wojny w roku 1947 na rynku wydawniczym ukazał się „Przegląd Historyczno-Oświatowy” i, jak głosił podtytuł, jako kwartalnik poświęcony ,badaniom dziejów wychowania i oświaty w Polsce". Wydawany był wówczas w Krakowie, zaś redaktorem został Jan Hulewicz. Pismo zostało powołane z inicjatywy Komisji do Badania Dziejów Oświaty i Wychowania Związku Nauczycielstwa Polskiego i planowane było jako organ tej Komisji ${ }^{14}$. Wskazując na ogrom zniszczeń wojennych archiwaliów poniesionych także w obszarze dziejów oświaty i wychowania, w słowie wstępnym (Od Redakcji) napisano: „Na tle tych spustoszeń rośnie waga i znaczenie żywej tradycji zawartej we wspomnieniach świadków i współtwórców wysiłków pedagogicznych zbiorowości polskiej. Pobudzić do pisania wspomnień działaczy pedagogicznych, którzy znają z autopsji dzieje szkoły zaborczej i nasza walkę o oświatę w drugiej połowie XIX i początku XX w. to mogłoby nam bodaj częściowo wyrównać straty poniesione w materiale archiwalnym" "15. Profil pisma zakreślono następująco:

„Przegląd Historyczno-Oświatowy” pragnie na swych łamach dawać oświetlenie faktów przeszłości oświatowej, przede wszystkim najbliższej z okresu lat 1864-1945 wytwarzającej demokratyczne tradycje walk o szkołę polską, nie rezygnując naturalnie także z oświetlenia przeszłości dalszej. Pragniemy w stałych działach kwartalnika - rozpraw, materiałów, recenzji, materiałów ilustracyjnych, bibliografii - pogłębiać tego okresu. Szczególną wagę przywiązujemy do ogłaszania ciekawych wspomnień i dokumentów. Apelujemy o pomoc i współpracę do tych wszystkich, spośród pracowników naukowych i nauczycielstwa, dla których nasza przeszłość pedagogiczna, nasz wysiłek tworzenia szkoły polskiej jest treścią żywą ${ }^{16}$.

Jednak po ukazaniu się czterech zeszytów pismo zawieszono, aby wznowić w 1959 r. i odtąd redakcję przenieść do Warszawy, gdzie mieści się do chwili obecnej.

${ }^{12}$ Od Redakcji, ,Minerwa Polska” 1930, s. VI.

${ }^{13} \mathrm{O}$ próbach powołania wydawnictw historyczno-oświatowych patrz: W. Szulakiewicz, Historia oświaty $i$ wychowania w Polsce 1944-1956, Kraków 2006, s. 43-89.

${ }^{14}$ Od Redakcji, „Przegląd Historyczno-Oświatowy” 1947, s. 3-4.

${ }^{15}$ Ibidem, s. 4.

${ }^{16}$ Ibidem. 
Jego redaktorem w chwili wznowienia pozostał Ryszard Wroczyński, sprawując tę funkcję do śmierci, czyli w 1987 r. ${ }^{17}$ Do współpracy zapraszano pracowników naukowych i nauczycieli. We wznowionym „Przeglądzie Historyczno-Oświatowym” w notatce $O d$ Redakcji możemy przeczytać: „W czasopiśmie zamieszczać będziemy rozprawy i materiały zarówno z dziejów szkoły, jak i pozaszkolnej pracy społeczno-oświatowej"18. W okresie 60-lecia struktura „Przeglądu Historyczno-Oświatowego” w zasadzie nie uległa zmianie i tworzą ją: Artykuty i rozprawy, Materiały, Sylwetki, Recenzje i Noty bibliograficzne, Bibliografie i Kronika ${ }^{19}$. W niektórych zeszytach pojawiają się: Listy, polemiki i dyskusje.

W latach 1948-1958, czyli przez 10 lat, historycy wychowania nie mieli swojego organu prasowego. Dopiero w 1958 r. staraniem Łukasza Kurdybachy pierwszego redaktora - oraz dzięki przychylności władz Polskiej Akademii Nauk (PAN) powołano do życia „Rozprawy z Dziejów Oświaty”, jako jedno z wydawnictw Pracowni Dziejów Oświaty $\mathrm{PAN}^{20}$. W założeniu redakcji pismo to miało stanowić organ, w którym publikowane byłyby drobniejsze prace $\mathrm{z}$ dziejów oświaty ważne jednak dla rozwoju nauki ${ }^{21}$. Ich autorami, jak napisał Ł. Kurdybacha, winni być nie tylko doświadczeni badacze, ale także wybijający się młodsi pracownicy naukowi, których osiągnięcia badawcze i metodologiczne, zdaniem Kurdybachy, zasługiwały na rozpowszechnienie. Po śmierci Ł. Kurdybachy (1972) redakcję pisma przejął J. Miąso i sprawował do roku 2009, od tego roku funkcję redaktora naczelnego przejęła Joanna Schiller. Analiza „Rozpraw...”, które istnieją ponad pół wieku wykazuje, iż jej podstawowe działy to: Rozprawy, Recenzje i Sprawozdania, a w niektórych rocznikach uzupełnia je dział pt. Materiaty.

I wreszcie ostatni periodyk, „Biuletyn Historii Wychowania”, który jest najmłodszym ze wspomnianych pism, bo obchodzącym w bieżącym roku, tj. w 2010, dopiero szesnastolecie swego istnienia. Swój początek zawdzięcza inicjatywie członków Sekcji Historii Wychowania, funkcjonującej w ramach

${ }^{17}$ Wówczas do składu Redakcji weszli: R. Wroczyński, J. Hulewicz, T. Nowacki, T. Wojeński. Radę Redakcyjną tworzyli: H. Barycz, J. Dobrzański, J. Kwiatek, W. Polkowski, S. Tync. Redakcję pisma po R. Wroczyńskim przejął Marian Walczak.

${ }^{18}$ Od Redakcji, „Przegląd Historyczno-Oświatowy”1959, s. 3. Notatka była zbyt lakoniczna i wspomniano szerzej o początkach pisma.

${ }^{19}$ Trzeba zaznaczyć, iż nie we wszystkich zeszytach znajduje się dział Kronika, Bibliografia.

${ }^{20}$ Od Redakcji, „Rozprawy z Dziejów Oświaty” 1958, s. 3. Więcej informacji o genezie powstania pisma w: W. Szulakiewicz, „Rozprawy z Dziejów Oświaty”1958-2003. Studium z historii czasopisma, Toruń 2004, s. 26-31.

${ }^{21}$ W skład pierwszego Kolegium Redakcyjnego wchodzili: Ludwik Chmaj, Marian Falski, Rafał Gerber, Łukasz Kurdybacha. W następnych latach skład Kolegium poszerzono o następujące osoby: Jan Dobrzański (1959), Ignacy Zarębski (1965), Eugenia Podgórska (1970), Stanisław Mauersberg (1980), Lech Mokrzecki, Kamilla Mrozowska i Leonard Grochowski (1984), Tadeusz Bieńkowski i Leszek Zasztowt (1992) i Irena Szybiak (2000). 
Polskiego Towarzystwa Pedagogicznego"22. W pierwszym numerze „Biuletynu Historii Wychowania” z 1994 r. zamieszczona notka Od Redakcji zawierała informacje o profilu i programie wydawnictwa.

W naszym piśmie pragniemy m.in.: zamieszczać artykuły i rozprawy przedstawiające rezultaty najnowszych badań w dziedzinie historii edukacji, a także refleksje z zakresu metodologii i teorii historii wychowania o istotnym znaczeniu dla tego fragmentu procesu dziejowego, dokonywać prezentacji ośrodków zajmujących się badaniami w zakresie dziejów oświaty i myśli pedagogicznej oraz upowszechnianiu ich rezultatów, informować o szerszym ruchu naukowym i wydawniczym odnoszącym się do tej dziedziny, jak również o wysiłkach organizacyjnych w zakresie integracji środowiska historyków wychowania (w wymiarze krajowym i międzynarodowym) - tak brzmiała odezwa Redakcji przedstawiona w pierwszym numerze pisma ${ }^{23}$.

Od momentu powołania „Biuletynu Historii Wychowania” funkcję redaktorów pełnią Dorota Żołądź-Strzelczyk i Wiesław Jamrożek.

Struktura pisma na przestrzeni omawianego okresu zmieniała się. Od roku 1994 do 2001 w czasopiśmie funkcjonowały następujące działy: Artykuły i rozprawy, Z kalendarza historycznego, Prezentacje, Ksiażki oraz Sesje i Konferencje naukowe. W latach 1994-1996 w strukturze „Biuletynu” wyszczególniono dział zatytułowany $Z$ życia Sekcji Historii Wychowania. W niektórych rocznikach dodatkowo wyróżniono takie działy jak: Dyskusje i polemiki (1999) czy Komunikaty (2001).

Od 2002 r. „Biuletyn Historii Wychowania” stał się organem Towarzystwa Historii Edukacji ${ }^{24}$. Konsekwencją tej decyzji była zmiana dotychczasowej struktury pisma, a dokładniej pojawienie się zupełnie nowych działów, a są to Materiaty i Kronika Towarzystwa Historii Edukacji oraz zmiany w nazwach dotychczasowych działów. Dotychczasowy dział Ksiażki nosi tytuł Wydawnictwa, z kolei dział Sesje i Konferencje Naukowe zatytułowano Życie Naukowe, a w nim odnotowywano sprawozdania $z$ odbytych konferencji naukowych i zapowiedzi mających się odbyć sesji i konferencji. Funkcję informacyjną spełniał dział Komunikaty. Zmieniony i poszerzony został skład Rady Redakcyjnej o członków Towarzystwa Historii Edukacji. Wśród dotychczasowych Wydawców znalazł się Zarząd Główny Towarzystwa Historii Edukacji w Warszawie.

Poddając analizie kolejne roczniki czasopisma bez wątpienia można stwierdzić, że jego program sformułowany w 1994 r. był realizowany w opublikowa-

${ }^{22}$ Wydawcami, jak głosi zapis w pierwszym numerze pisma byli: Wydawnictwo Eruditus s.c. w Poznaniu, Zakład Historii Wychowania UAM i Sekcja Historii Wychowania PTP. Analizie dla potrzeb niniejszego artykułu zostały poddane dotychczas opublikowane numery pisma, $\mathrm{tj}$. za lata 1994-2007.

23 „Biuletyn Historii Wychowania” 1994, nr 1, s. 1.

${ }^{24}$ Decyzję taką podjęto podczas posiedzenia Zarządu Głównego Towarzystwa Historii Edukacji w dniu 7.03.2002 r. w porozumieniu z dotychczasowymi Wydawcami. Patrz: „Biuletyn Historii Wychowania” 2002, s. 169. 
nych dotychczas numerach periodyku. Wprowadzone zaś zmiany w strukturze pisma od 2002 roku oraz ocena zamieszczanych materiałów przez specjalnie wyznaczanego recenzenta każdego numeru ugruntowują pozycję naukową tegoż wydawnictwa.

Z ogólnego opisu struktury pism wynika, że podstawowe ich działy to: artykuły (bądź artykuły i rozprawy), materiały i recenzje. Można jednak stwierdzić, że to, co charakteryzuje czasopisma, to objętość poszczególnych działów. S. Łempicki dbał o dział recenzji. W „Rozprawach z Dziejów Oświaty” najwięcej miejsca zajmują artykuły, stanowiące efekt prezentacji wyników badań naukowych. Z kolei w „Biuletynie Historii Wychowania” mniej miejsca zajmują artykuły i rozprawy w stosunku do pozostałych działów czasopisma. Podobnie rzecz się ma, jeśli chodzi o strukturę w „Przeglądzie Historyczno-Oświatowym”. Chociaż w tym ostatnim więcej miejsca niż w innych pismach zajmuje dział Materiały. Na uwagę zasługuje też dział „Przeglądu” pt. Sylwetki, w którym prezentowane są biogramy wybitnych działaczy oświatowych, nauczycieli lub uczonych. Nieco inny wymiar ma także dział pt. Kronika stanowiący ważną część tego periodyku. W tym dziale poza relacjami ze zjazdów, sesji naukowych i konferencji prezentowane są historie szkół ,jubilatek" i szkół zasłużonych dla edukacji Polaków.

Jednak jak wszystkie funkcjonujące czasopisma naukowe i pisma z zakresu historii wychowania nie pozostają obojętne na ważne wydarzenia, dlatego na swoich łamach dokumentują je. Jednym z przejawów tego typu działalności były i są artykuły poświęcone jubileuszom wybitnych historyków wychowania, seminariom i sympozjom jubileuszowym czy wspomnieniom pośmiertnym, zamieszczane w „Rozprawach z Dziejów Oświaty”, jak i w „Biuletynie Historii Wychowania".

\section{Opiniotwórcza rola czasopism historyczno-oświatowych}

Zadanie informowania środowiska o dorobku naukowym, a także jego ocenę dobrze wypełniały i wypełniają ukazujące się recenzje publikacji historyczno-oświatowych. Dział pt. Recenzje jest bogaty poznawczo. Przedstawiając kwestie recenzji w poszczególnych pismach bezsprzecznie trzeba stwierdzić, że ich redakcje troszczyły się i troszczą o ten dział. Tezę tę warto poprzeć danymi statystycznymi obrazującymi liczbę recenzji w poszczególnych czasopismach.

Rozpoczynając od „Minerwy Polskiej” na jej łamach opublikowano ponad 70 recenzji prac $\mathrm{w}$ języku polskim, niemieckim i włoskim ${ }^{25}$. Przy czym ocenie

${ }^{25}$ Szerzej na ten temat piszę w: W. Szulakiewicz, „Minerwa Polska”-czasopismo naukowe..., s. 98-102. 
poddanych zostało znacznie więcej prac, niekiedy bowiem omawiano cykl publikacji na określony temat lub też kolejne numery czasopism.

Z kolei w „Przeglądzie Historyczno-Oświatowym” z lat 1947-2007 odnajdujemy 525 recenzji, wśród których przeważają publikacje wydawnictw polskich, chociaż pojawiają się i informacje o wydawnictwach niemieckich, czeskich, francuskich, litewskich, angielskich ${ }^{26}$. Wypowiedzi recenzyjne uzupełniają 32 noty bibliograficzne.

Wiele recenzji ukazało się także w „Rozprawach z Dziejów Oświaty”. „Rozprawy” w latach 1958-2009 zamieściły w sumie 268 recenzji, w tym ponad 80 publikacji w języku obcym. Należy zauważyć, iż w tym piśmie polskiemu czytelnikowi przybliżono piśmiennictwo historyczno-oświatowe niemieckie, francuskie, amerykańskie. W „Rozprawach z Dziejów Oświaty” w grupie prac obcojęzycznych dominowały omówienia wydawnictw w języku niemieckim, na kolejnych miejscach znajdują się recenzje publikacji w językach francuskim, czeskim i słowackim, angielskim ${ }^{27}$.

Analizując recenzje wydawnictw zagranicznych zauważa się, iż przeważa prezentacja czasopism i ich zawartości, ale są ocenione także ważne prace zwarte. Z publikacji zwartych prócz książek autorskich omówione zostały wydawnictwa zbiorowe, będące efektem współpracy europejskich historyków, bądź materiałami pokonferencyjnymi. Zdarzają się także recenzje serii wydawniczych, jako przykład można podać recenzje serii wydawanej pod red. Stanisława Litaka ${ }^{28}$. Ze względu na tematykę recenzowane prace dotyczą stanu badań, zagadnień metodologicznych i ważnych zjawisk w dziejach edukacyjnych danego kraju. Wartość ogłoszonych recenzji wynika z faktu, iż w znakomitej części pisali je wytrawni badacze historii oświaty i wychowania.

Natomiast na łamach „Biuletynu Historii Wychowania” w dotychczasowych rocznikach zamieszczono 119 recenzji i 61 not $^{29}$. Przez cały okres ukazywania się pisma drukowano recenzje dzieł głównie polskich. Niewiele odnajdziemy recenzji prac w języku obcym, bo jedynie 3, niewiele też informacji na ten temat znajdujemy wśród not. W tym zakresie „Biuletyn Historii Wychowania” różni się znacząco od „Rozpraw z Dziejów Oświaty”. Te ostatnie drukują najwięcej informacji o publikacjach historyczno-oświatowych wydawanych w innych krajach.

We wszystkich omawianych czasopismach dział Recenzji spełnia zatem ważną funkcję poznawczą i krytyczną wobec dyscypliny, którą reprezentują.

\footnotetext{
${ }^{26} \mathrm{~W}$ obliczeniach opieram się na Bibliografii zamieszczonej w „Przeglądzie Historyczno-Oświatowym" z 2007 r.

${ }^{27}$ Szerzej na ten temat: W. Szulakiewicz, Rozprawy z Dziejów Oświaty” (1958-2002). Studium z historii czasopisma, Torun 2004.

${ }^{28}$ J. Miąso, Prace z historii szkolnictwa w Polsce, „Rozprawy z Dziejów Oświaty” 2005, t. XLIV, s. 211-216.

${ }^{29}$ Dotychczas, tj. w latach 1994-2008, ukazały się 23 numery czasopisma.
} 
A szczegółowiej określając, według przyjętej w literaturze klasyfikacji, są to funkcje: informacyjna, bibliograficzna i oceniająca. Dzięki tym funkcjom są periodykami pozwalającymi czytelnikowi wyrobić sobie opinie o aktywności polskiego środowiska historyków wychowania w zakresie piśmiennictwa historyczno-oświatowego, jak też znajomości dorobku wydawniczego z zakresu historii wychowania w innych krajach.

\section{Czasopisma historyczno-oświatowe o życiu naukowym środowiska historyków edukacji}

Rangę dobrze spełnianej funkcji: informacyjnej (w zakresie danych o życiu naukowym) oraz kronikarskiej ${ }^{30}$ czasopism doceniają przede wszystkim historycy nauki. Dzięki nim bowiem każde czasopismo staje się poważnym, a niekiedy pierwszym źródłem wiedzy o życiu naukowym środowisk. Informacje o konferencjach, kongresach, sympozjach naukowych, powstawaniu instytucji czy towarzystw naukowych to dane, które niekiedy stanowią punkt wyjścia do dalszych badań nad rozwojem określonej dyscypliny. Przede wszystkim są to wiadomości o różnych formach organizacji badań prowadzonych przez dane środowisko. Trzeba mieć jednak świadomość, iż funkcje te nie mogą być traktowane samoistnie nawet, a może przede wszystkim, przez historyków nauki, powinny one być uzupełniane przez funkcję bibliograficzną polegającą na rejestracji dorobku wydawniczego danej dziedziny wiedzy oraz funkcję anonsująca. Celem tej ostatniej jest prezentacja wyników badań w postaci „małych form" literatury naukowej, czyli publikacja nie ogłoszonych jeszcze w druku fragmentów prac będących zwiastunem poważniejszych wydawnictw.

Należy zatem zapytać, $w$ jakim stopniu omawiane czasopisma pełnią funkcję informatora z życia naukowego środowiska historyków oświaty?

Omawiane tu czasopisma rejestrują spotkania naukowe. Wśród sprawozdań z konferencji, omówień sympozjów, kongresów naukowych znajdują się relacje o spotkaniach organizowanych przez różne polskie ośrodki akademickie. Utrwalony został także udział polskich historyków wychowania w konferencjach naukowych organizowanych za granica.

Jako przykład można podać notatki o międzynarodowych konferencjach organizowanych pod patronatem stowarzyszenia o nazwie Międzynarodowa Stała Konferencja Historyków Wychowania (ISCHE) skupiającego specjalistów tej dziedziny niemal z całego świata. Stowarzyszenie to organizuje corocznie

\footnotetext{
${ }^{30}$ Funkcji kronikarskiej w omawianym piśmie jako roczniku ze względu na długi cykl wydawniczy (do niedawna) nie można przecenić, bardziej należy mówić o funkcji informacyjnej.
} 
konferencje już od roku $1979^{31}$. Notatki na ten temat zamieszczono zarówno w „Rozprawach z Dziejów Oświaty”, jak i w „Biuletynie Historii Wychowania”. Warto odnotować, że taka konferencja odbyła się w Polsce już w 1980 r., o czym informują „Rozprawy z Dziejów Oświaty”32.

O kolejnym tego typu spotkaniu w Polsce zamieszczono informację w „Biuletynie Historii Wychowania” z zasygnalizowaniem programu XVIII Międzynarodowej Konferencji Historyków Wychowania, która odbyła się w 1996 roku w Krakowie ${ }^{33}$. Organizatorem spotkania była Katedra Historii Oświaty i Wychowania WSP w Krakowie (obecnie Akademia Pedagogiczna), a animatorem przedsięwzięcia profesor Czesław Majorek. Udział w XVIII spotkaniu zgłosiło 160 osób z 29 krajów, zaś Polskę reprezentowały 24 osoby. Uczestnicy dyskutowali na temat szkolnictwa w zmieniających się społeczeństwach w perspektywie historycznej i porównawczej.

Wspomniane czasopisma dokumentują również polskie konferencje naukowe. Spotkania naukowe, zorganizowane $\mathrm{z}$ inicjatywy polskich środowisk, miały charakter bądź ogólnopolski, bądź międzynarodowy. Niekiedy konferencje czy sympozja naukowe połączone były z jubileuszami pracy wybitnych historyków wychowania. Wówczas to do sprawozdań z obrad konferencyjnych dołączane są informacje o życiu i działalności naukowej jubilatów. Przykładowo warto podać, jak w tym zakresie funkcję informacyjną spełniają „Rozprawy z Dziejów Oświaty” i „Biuletyn Historii Wychowania”.

W „Rozprawach z Dziejów Oświaty” z 1989 r. zarejestrowano przebieg sesji naukowej pt. „Historia wychowania - badanie - nauczanie”, która odbyła się w Krakowie i połączona była z jubileuszem pracy prof. K. Mrozowskiej ${ }^{34}$. Inna w tej grupie tematycznej konferencja pt. „Historia - nauczanie” miała miejsce w Gdańsku w roku 1996, połączona została z uroczystością jubileuszową profesora Lecha Mokrzeckiego ${ }^{35}$. W 2004 r. w Pułtusku odbyło się seminarium naukowe połączone z jubileuszem profesora Józefa Miąso ${ }^{36}$.

${ }^{31} \mathrm{~W}$ roku 1980 w Jabłonnie koło Warszawy została zorganizowana (z inicjatywy Komitetu ISCHE) przez Instytut Historii Nauki i Techniki PAN II międzynarodowa konferencja z cyklu ISCHE.

${ }^{32}$ J. Miąso, Międzynarodowa konferencja historyków oświaty (Jabłonna 24-27 IX 1980), „Rozprawy z Dziejów Oświaty” 1983, s. 93-105.

33 „Biuletyn Historii Wychowania” 1995; także: J. Ryś, (Sprawozdanie) XVIII Międzynarodowa Stała Konferencja Historyków Wychowania „Szkolnictwo w zmieniających się społeczeństwach. Badania historyczne i porównawcze (ok. 1750-1996)". Kraków, 6-9 sierpnia 1996, „Rozprawy z Dziejów Oświaty” 1998, t. XXXVIII, s. 187-188.

${ }^{34}$ Sesja odbyła się w 1987 r. Patrz: „Rozprawy z Dziejów Oświaty” 1989.

${ }^{35}$ B. Michalik, Ogólnopolska konferencja historyków wychowania. Historia - edukacja, „Rozprawy z Dziejów Oświaty” 1998, t. XXXVIII, s. 185-186. Jubilatowi wręczono księgę pt. Szlakami przeszłości i czasów współczesnych, red. K. Puchowski i J. Żerka, Gdańsk 1996.

${ }^{36}$ A. Fijałkowski, Atlas historyczny szkót w Polsce, Puttusk 22-24 lutego 2000, „Rozprawy z Dziejów Oświaty” 2000, s. 215-216; J. Romanowska, J. Dąbrowska, Jubileusz Profesora Józefa Miaso, „Biuletyn Historii Wychowania” 2004, s. 128-129. 
„Biuletyn Historii Wychowania” także utrwala tego typu spotkania. I tak na jego łamach możemy przeczytać, iż w Krakowie w 1994 r. w Wyższej Szkole Pedagogicznej odbyło się Ogólnopolskie Spotkanie Historyków Wychowania połączone z jubileuszem pracy naukowej profesora Zygmunta Ruty. Celem spotkania poza intencją jubileuszową była dyskusja nad przygotowaniem merytorycznym i organizacyjnym polskiego środowiska do XVIII Międzynarodowej Stałej Konferencji Historyków Wychowania, która miała odbyć się w Krakowie ${ }^{37}$. Z kolei w roczniku z 2005/2006 przedstawiono przebieg jubileuszu 70-lecia urodzin profesor Danuty Koźmian i 75-lecia urodzin profesora Zygmunta Ruty.

Czytelnik w dziale Sesje i konferencje naukowe (po zmianie Życie naukowe) „Biuletynu” odnajdzie informacje o uczestnictwie historyków wychowania w Zjazdach Pedagogicznych. I tak kolejno w 1995 r. w Toruniu miał miejsce II Ogólnopolski Zjazd Pedagogiczny. Relację z obrad Sekcji Historyków Wychowania przynosi sprawozdanie przedstawiające uczestników dyskusji oraz jej przebieg $^{38}$. O tym wydarzeniu napisano także w „Rozprawach z Dziejów Oświaty”39. W „Biuletynie Historii Wychowania” odnotowano także kolejne Zjazdy Pedagogiczne. W 1998 r. zjazd pedagogów, w którym uczestniczyli historycy wychowania, odbył się w Poznaniu, a w 2001 r. w Olsztynie.

Wspomnieć także należy o informacjach dotyczących procesu instytucjonalizacji polskiej historii wychowania. Oto kilka danych odnotowanych w interesujących nas czasopismach. Rok 2000 był ważny dla naszej dyscypliny, tj. historii wychowania. Podczas dyskusji nad atlasem historycznym szkół w Polsce, która miała miejsce w Pułtusku, zastanawiano się także nad problemem integracji środowiska polskich historyków wychowania. Profesor Józef Miąso zaproponował utworzenie organizacji skupiającej potencjalnie wszystkie środowiska badaczy przeszłości oświatowej o nazwie Towarzystwo Historii Edukacji (THE) ${ }^{40}$. Inicjatywę tę zaakceptowali wszyscy zebrani, a jako komitet założycielski uznano uczestników konferencji. Ustalono, iż statut Towarzystwa zostanie opracowany przez historyków wychowania PAN i UW. 19 grudnia 2001 r. w gmachu Wydziału Pedagogicznego Uniwersytetu Warszawskiego odbyło się Nadzwyczajne Zebranie Towarzystwa. Celem jego zwołania było przedstawienie i poddanie pod dyskusję wypracowanego przez Zarząd Towarzy-

${ }^{37}$ W. J., „Biuletyn Historii Wychowania” 1995, s. 60-61. Podczas spotkania prof. Z. Rucie wręczono księgę jubileuszową pt. Prace z Historii Oświaty $i$ Wychowania. IV, red. J. Krukowski i C. Majorek, Kraków 1994.

${ }^{38}$ J. Hellwig, „Biuletyn Historii Wychowania” 1996, s. 78-79.

${ }^{39}$ M. Strzelecki, Historia wychowania - przesłania dla wspótczesności. Sprawozdanie z obrad historyków wychowania II Ogólnopolskiego Zjazdu Pedagogicznego w Toruniu, „Rozprawy z Dziejów Oświaty" 1996, s. 208-211.

${ }^{40} \mathrm{Na}$ ten temat: I. Szybiak, Towarzystwo Historii Edukacji, „Biuletyn Historii Wychowania” 2002, s. $164-168$. 
stwa planu działania i zakresu najpilniejszych prac. Referat programowy na temat podstawowych celów i kierunków działalności Towarzystwa Historii Edukacji wygłosiła jego przewodnicząca profesor Irena Szybiak. Zebraniu towarzyszyła dyskusja dotycząca m.in. najpilniejszych prac badawczych, zespołów badawczych oraz inicjatyw wydawniczych. Jej rezultatem było podjęcie uchwały o przyjęciu programu THE oraz przekształceniu „Biuletynu Historii Wychowania" w organ Towarzystwa ${ }^{41}$.

Sprawozdania z odbytych konferencji i sympozjów naukowych ukazują nie tylko obszary i kierunki aktywności środowiska historyków wychowania, ale i kierunki współpracy historyków wychowania z innymi środowiskami ${ }^{42}$.

Trzeba podkreślić, że ważną rolę jako informator odgrywa dział „Biuletynu" pt. Prezentacje. To w nim w odnajdujemy skrótowe opisy rozwoju historii wychowania w poszczególnych ośrodkach akademickich, przebieg procesu instytucjonalizacji, rozwoju naukowego polskich środowisk akademickich. Jak dotąd zaprezentowane zostały następujące uczelnie, a w nich historia wychowania: Uniwersytet Gdański, Uniwersytet Mikołaja Kopernika, Uniwersytet Opolski, Uniwersytet im. Adama Mickiewicza w Poznaniu, Uniwersytet Rzeszowski, Uniwersytet Szczeciński, Uniwersytet Warmińsko-Mazurski, Wyższa Szkoła Pedagogiczna w Kielcach, Akademia Pedagogiczna w Krakowie i Pomorska Akademia Pedagogiczna w Słupsku ${ }^{43}$.

I na zakończenie uwag o ważności informacji o polskim środowisku naukowym trzeba wspomnieć o Ogólnopolskim Konkursie Prac Magisterskich z Historii Wychowania. Dane na ten temat znajdują się w organie prasowym THE, czyli „Biuletynie Historii Wychowania”44.

\section{Zakres informacji o polskiej historii wychowania na lamach czasopism historyczno-oświatowych}

Czasopisma, jak już wspomniano, ze względu na znajdujące się w nich działy, tj.: artykuły, recenzje, materiały, spełniają porównywalne funkcje poznawcze, jednak pewne drobne różnice wynikające z: 1) programu i struktury, a szczególnie troski poszczególnych redakcji o niektóre działy pism, 2) czasu powstania, czynią każde z nich specyficznym źródłem historycznym.

\footnotetext{
${ }^{41}$ Ibidem.

${ }^{42}$ Opierając się tylko na tych czasopismach jako źródle do dziejów polskiej historii wychowania można zauważyć zmniejszający się udział przedstawicieli historii wychowania w Ogólnopolskich Zjazdach Pedagogicznych począwszy od zjazdu we Wrocławiu, a następnie w Lublinie.

${ }^{43}$ Należy mieć nadzieję, że w dalszych numerach „Biuletynu” zostaną przedstawione pozostałe ośrodki akademickie w zakresie historii wychowania. Brak prezentacji ośrodka warszawskiego, wrocławskiego, katowickiego i łódzkiego.

44 „Biuletyn Historii Wychowania” 2003, 2004, 2007.
} 
Wszystkie dotychczas opublikowane czasopisma stanowią źródło do polskiej historii wychowania. Jednak, jak twierdzą metodolodzy historii, źródło pełni swoje funkcje jeśli badacz sformułuje odpowiednie pytania. Analiza zawartości poszczególnych czasopism pozwala na przedstawienie wielu pytań i w konsekwencji wysunięcie kilku tez, wskazujących na ich znaczenie jako źródła do dziejów polskiej historii wychowania. Oto tylko niektóre z pytań, które należałoby uwzględnić analizując wspomniane periodyki:

Jakie znaczenie na profil pisma (miał) ma skład redakcji i redaktorzy?

Jeśli omówione tu czasopisma traktujemy jako źródło do dziejów polskiej historii wychowania, to nie sposób nie wspomnieć o osobach redaktorów i członków rad redakcyjnych czy kolegiów. Bowiem o ile współcześnie skład redakcji tworzą historycy wychowania, o tyle u początków funkcjonowania czasopism historyczno-oświatowych w spisach kolegiów znajdujemy przedstawicieli innych subdyscyplin historycznych. A to także jest przejawem rozwoju polskiej historii wychowania.

Kim byli twórcy wspomnianych czasopism? Zacznijmy od najstarszego pisma, czyli „Minerwy Polskiej”.

Otóż Kolegium redakcyjne „Minerwy” oprócz historyków wychowania (S. Łempickiego, S. Kota, S. Tynca) tworzyli historyk kultury i historyk Kościoła, badacz dziejów UJ, ks. Jan Fijałek oraz lekarz antropolog i historyk medycyny, twórca Archiwum Historii Medycyny i „Przeglądu Antropologicznego" Adam Wrzosek.

W skład Kolegium redakcyjnego „Rozpraw z Dziejów Oświaty” oprócz Ł. Kurdybachy weszli Marian Falski - pedagog, działacz oświatowy, Ludwik Chmaj - filozof i pedagog oraz Rafał Gerber - historyk dziejów powszechnych, archiwista, edytor $^{45}$. I na koniec warto przywołać w tym kontekście skład redakcji „Przeglądu Historyczno-Oświatowego”. Do grona osób tworzących „Przegląd Historyczno-Oświatowy” w 1947 r. weszli jako członkowie Komitetu Redakcyjnego: Stanisław Brzozowski, Karol Klimek, Eugeniusz Müller i Czesław Wycech. Natomiast w skład redakcji z 1959 r., obok historyków wychowa$n^{4}{ }^{46}$, weszli przedstawiciele reprezentujący ZNP - Teofil Wojeński i Wacław Polkowski, jak też inicjator Poznańskiego Towarzystwa Pedagogicznego i jego prezes zarazem - Józef Kwiatek.

Od początku funkcjonowania pisma do tego grona należy zaliczyć również: Tadeusza Nowackiego wchodzącego w skład Komitetu Redakcyjnego od 1959 r., w kolejnych latach Karola Poznańskiego i Lecha Mokrzeckiego, Renatę Dutkową, Stanisława Mauersberga, wreszcie Mariana Walczaka jako redaktora od 1988 r., wcześniej wchodzącego w skład Rady Redakcyjnej.

\footnotetext{
${ }^{45}$ To on przyczynił się do wydania dekretu w 1951 roku nadającego placówkom archiwalnym status instytucji naukowych.

${ }^{46}$ Skład Rady Redakcyjnej (przyp. 17), podaję za: T. Gumuła, Czterdzieści pięć lat „Przegladu Historyczno-Oświatowego", s. 80-83.
} 
Nie zmienili się także redaktorzy „Biuletynu Historii Wychowania” od początku jego powstania ${ }^{47}$.

$\mathrm{Z}$ analizy tego aspektu czasopism wynika, że, bez wątpienia, biografie naukowe osób tworzących redakcje poszczególnych pism, począwszy od tych najstarszych do najmłodszego, czyli „Biuletynu Historii Wychowania”, ukazują pewne trendy w rozwoju tej dyscypliny. Jak wynika bowiem z wcześniejszych uwag, pierwszymi pismami kierowali przedstawiciele różnych subdyscyplin historycznych, zaś dzisiaj w składach redakcji zasiadają historycy wychowania. To zapewne miało i ma wpływ na tematykę zamieszczanych artykułów i rozpraw.

Szczególny szacunek należy oddać tym historykom wychowania, których związki z czasopismami są wieloletnie i sięgają niekiedy daty ich powstania. Przykładowo w roku 2008 minęło pół wieku współpracy Józefa Miąso z „Rozprawami z Dziejów Oświaty" najpierw jako sekretarza, a później redaktora. Ponadto od wielu lat, tj. od 1973 r. związany jest on także z "Przeglądem Historyczno-Oświatowym”. Członkiem Kolegium Redakcyjnego „Rozpraw” od 1977 r. jest Kalina Bartnicka, od 1980 r. Stanisław Mauersberg, zaś od 1984 r. Lech Mokrzecki.

Jaka jest relacja między wydawcą a profilem pisma? Co wynika dla profilu czasopisma $\mathrm{z}$ faktu bycia organem prasowym określonej organizacji czy towarzystwa naukowego?

Na profil pism wpływało i wpływa także to, jaką instytucję naukową czy towarzystwo lub związek reprezentuje dany organ prasowy oraz kto jest wydawcą. I tu warto nadmienić, że najstarsze czasopismo - „Minerwa Polska” Komisji do Badania Dziejów Wychowania i Szkolnictwa w Polsce, jednak już drugi rocznik „Minerwy” po rozwiązaniu Komisji (1929) ukazał się w 1930 r. jako organ Komisji Historycznej Naukowego Towarzystwa Pedagogicznego. „Rozprawy z Dziejów Oświaty” od początku swego powstania związane są z jedną instytucją naukową, czyli Polską Akademią Nauk. „Przegląd Historyczno-Oświatowy" do 1991 r. był organem Związku Nauczycielstwa Polskiego, a od 1992 r. Polskiego Towarzystwa Pedagogicznego. Wreszcie „Biuletyn Historii Wychowania”, który w 15-leciu swego istnienia zmieniał przynależność: z organu reprezentującego Sekcję Historii Wychowania Polskiego Towarzystwa Pedagogicznego na organ Towarzystwa Historii Edukacji. Zmieniali się także jego wydawcy.

Jak przedstawia się przynależność zawodowa czy doświadczenie profesjonalne autorów współpracujących z czasopismem?

Trzeba podkreślić, że analizowane czasopisma różnią się ze względu na profesjonalizm i pochodzenie zawodowe oraz doświadczenie współpracowników. Otóż „Przegląd Historyczno-Oświatowy” jest najbardziej otwarty na autorów ze

\footnotetext{
${ }^{47}$ Natomiast Radę Redakcyjną w 1995 roku tworzyli: Jan Hellwig, Krzysztof Kabziński, Czesław Majorek, Lech Mokrzecki, Sławomir Sztobryn.
} 
środowisk pozaakademickich, badaczy regionalnych, działaczy oświatowych, nauczycieli różnych typów szkół, miłośników historii. Jest pismem dla nauczycieli, o nauczycielach. To się poniekąd przekłada na problematykę prezentowaną na jego łamach. „Rozprawy z Dziejów Oświaty” kontynuują zaś linię zapoczątkowaną przez Ł. Kurdybachę, czyli pozyskiwania autorów ze środowisk akademickich, zarówno doświadczonych badaczy, jak i młodszych pracowników naukowych. Z kolei z analizy „Biuletynu Historii Wychowania”, stosując kryterium doświadczenia jego autorów wynika, że wśród współpracowników dominują młodsi pracownicy nauki. Z tego też względu „Biuletyn Historii Wychowania" pełni także funkcję anonsującą.

Jaka problematyka dominuje w analizowanych czasopismach?

Bez wątpienia każde z omawianych tu czasopism jest miejscem popularyzacji dziejów oświaty i wychowania, zwłaszcza rodzimych, w mniejszym stopniu powszechnych. Jednak należy zapytać jaką wiedzę o polskiej historii wychowania przynosi każde z osobna. Przy czym przy określeniu ich wartości jako źródła pomijamy tu szczegółowe rozpatrywanie problematyki zamieszczanych opracowań, ograniczając się jedynie do ogólnych stwierdzeń.

Najstarsze polskie czasopismo z wymienionych wcześniej, czyli „Minerwa Polska", pomimo iż miało krótki żywot, jest zapisem początków profesjonalizacji i instytucjonalizacji polskiej historii wychowania. To tu znajdziemy wiedzę m.in. na temat:

- funkcjonowania Komisji do Badania Dziejów Wychowania i Szkolnictwa w Polsce i jej oddziałów

- programu i planów badawczych formułowanych przez ówczesnych badaczy przeszłości oświatowo-wychowawczej

- dorobku piśmienniczego z zakresu historii wychowania za lata 1924-1929 dzięki zamieszczonej bibliografii

- problematyki prowadzonych badań

- prób integracji środowiska historyków wychowania w latach międzywojennych.

„Przegląd Historyczno-Oświatowy” jako organ ZNP i PTP jest źródłem do dziejów:

- kształtowania się czy też organizowania środowiska historyków wychowania po II wojnie światowej

- polskiego środowiska nauczycielskiego

- polskich reform oświatowych

- historii szkół różnego typu

- polskiej oświaty w okresie wojny i okupacji

- polskich organizacji nauczycielskich.

Mniej jest natomiast informacji o działalności Polskiego Towarzystwa Pedagogicznego, chociaż jest to pismo tego towarzystwa. 
„Rozprawy z Dziejów Oświaty” są zaś dokumentem źródłowym mówiącym o:

- historii najważniejszych instytucji i wydarzeń oświatowych w Polsce na przestrzeni dziejów

- współpracy międzynarodowej polskich historyków wychowania

- metodologii historii wychowania

- zainteresowaniach polskich badaczy powszechną historią wychowania

- funkcjonowaniu historii wychowania i historyków wychowania w strukturach Polskiej Akademii Nauk.

Z kolei „Biuletyn Historii Wychowania” stanowi ważny dokument, zawierający informacje na temat:

- instytucjonalizacji polskiej historii wychowania w ostatnich 15-latach

- różnorodnych formach integracji środowiska historyków wychowania

- dorobku piśmienniczego z zakresu dziejów oświaty wychowania i kultury od 1992 r. do chwili obecnej, czego wyrazem są zamieszczane w każdym numerze bibliografie.

I na koniec jeszcze jedna kwestia warta przemyślenia. Analiza zawartości czasopism motywuje do postawienia wielu innych pytań związanych z jednej strony z ich historia, z drugiej zaś ze współczesnościa, przyszłością i kondycją. Oto niektóre $\mathrm{z}$ nich:

1. Dlaczego Naukowe Towarzystwo Pedagogiczne nie poczyniło starań, aby publikację „Minerwy Polskiej” kontynuować?

2. Jak to możliwe, że ZNP (Komisja do Badania Dziejów Oświaty i Wychowania) zdołał nie tylko powołać pismo (PHO), ale i wznowić jego publikację w 1959 r., a obecnie wciąż są trudności z utrzymaniem tegoż periodyku?

3. Dlaczego „Przegląd Historyczno-Oświatowy” przeżywa od lat 90-tych „grozę" zamknięcia, a Polskie Towarzystwo Pedagogiczne nie wykazuje tą sprawą zainteresowania?

4. Czy i na ile zmienił się profil pisma i w jakim zakresie po przejęciu patronatu przez Polskie Towarzystwo Pedagogiczne?

Odpowiedzi tylko na te pytania (i inne) mogą być przyczynkiem do zobrazowania kwestii stosunku przedstawicieli pedagogiki (nauk pedagogicznych) do jej historii, a jednym z przejawów jest odniesienie się do sprawy popularyzacji przeszłości na łamach czasopism. 